\title{
Biological and economic performance of feedlot lambs feeding on diets with different energy densities ${ }^{1}$
}

\author{
Wandrick Hauss de Sousa ${ }^{2}$, Felipe Queiroga Cartaxo ${ }^{2}$, Roberto Germano Costa ${ }^{3}$, Marcílio \\ Fontes Cezar ${ }^{4}$, Maria das Graças Gomes Cunha ${ }^{2}$, José Morais Pereira Filho ${ }^{4}$, Neube Michel \\ dos Santos ${ }^{5}$
}

\footnotetext{
${ }^{1}$ Project financed by partnerships with FINEP/FAPESQ/EMEPA - PB.

${ }^{2}$ Empresa Estadual de Pesquisa Agropecuária da Paraíba - EMEPA-PB.

${ }^{3}$ Universidade Federal da Paraíba - UFPB.

${ }^{4}$ Universidade Federal de Campina Grande - UFCG.

${ }^{5}$ Agência Estadual de Vigilância Sanitária - AGEVISA-PB.
}

ABSTRACT - The objective of this study was to evaluate performance, carcass dressing and gross profit margin of lambs of different genotypes finished in feedlot with diets containing two levels of energy (2.40 Mcal/kg dry matter - DM or $2.90 \mathrm{Mcal} / \mathrm{kg} \mathrm{DM})$. Fifty-four non-castrated lambs of the following genotypes were used: Santa Inês, F1 Dorper $\times$ Santa Inês and F1 Santa Inês $\times$ undefined breed at approximately $150 \mathrm{~d}$ of age averaging $22.6 \mathrm{~kg}$ of live body weight. Lambs subjected to the diet containing $2.90 \mathrm{Mcal} / \mathrm{kg}$ DM stayed in feedlot for a shorter period of time. Moreover, they showed lower intake of dry matter and water in addition to greater daily weight gain and corporal score. There was interaction of feed conversion, carcass dressing yield and gross profit margin. The Dorper $\times$ Santa Inês lambs showed similar feed conversion in the two diets. However, Santa Inês lambs and Santa Inês $\times$ undefined breed lambs showed better feed conversion with the diet containing $2.90 \mathrm{Mcal} / \mathrm{kg} \mathrm{DM}$. The carcass dressings of the Santa Inês $\times$ undefined breed lambs were similar for both diets. Furthermore, the carcass dressing values were higher for the Santa Inês and Dorper $\times$ Santa Inês which received the diet with higher energy density. The gross profit margin is higher for Dorper $\times$ Santa Inês lambs in relation to genotype Santa Inês $\times$ undefined breed lambs when subjected to the diet with $2.40 \mathrm{Mcal} / \mathrm{kg} \mathrm{DM}$.

Key Words: average daily gain, Dorper, dry matter intake, feed conversion, Santa Inês, sheep

\section{Introduction}

Sheep meat production in the world exists in a large variety of environments under different production systems. According to MAPA (2009) Brazilian sheep meat production has not kept up with the increase in consumption, which led the country to import approximately 5.65 thousand tons of sheep meat in 2007.

The main economic factors that affect meat sheep production are a higher growth rate and feed conversion efficiency for the diet used. Camurça et al. (2002) stated that the strong dependency on the quantity and quality of available native pastures is the most important reason for the low productivity of ruminants. One of the options to solve this problem is the production as previously suggested (Oliveira et al., 2003), which is one alternative to lambs in feedlots systems. Siqueira et al. (2001) described the importance of working with intensive meat production systems, reducing the time period that lambs spend in feedlot and reducing the costs associated with feed as much as possible.
In feedlots, the diet used and the genotypes indicated for these systems are responsible for the biological and economic performances. Among the dietary components, energy is the most limiting factor in production and can reduce daily weight gain. A large number of factors affect the carcass and quality of sheep meat (Sañudo et al., 1998; Alfonso et al., 2001), which may, in turn, influence consumer satisfaction.

Sheep can have high productive indexes when their nutritional requirements are met, especially in their first six months of life. However, the current indexes of meat production in the country with breeds of hair sheep are far from being an ideal solution.

Among the hair sheep breeds, Santa Inês is a good option for meat production finishing in feedlot systems in Northeast Brazil due to average daily gain, dry matter intake, feed conversion and lean meat production (FurushoGarcia et al., 2006; Cartaxo et al., 2008). Furthermore, the Santa Inês breed can be used as a paternal and maternal breed in crossbreeding systems with females of undefined breed. The Dorper breed has been introduced in Brazil, 
recognized for its excellent potential in meat production, and brought new perspectives for crossbred genotypes between Dorper and lambs of undefined breed. The new perspective crossbred genotypes may also lead demand for development in commercial sheep meat.

The objective of this study was to evaluate lamb performance, carcass dressing yield and gross profit margin of purebred and crossbred lambs fed two different energydensity diets at finishing in feedlot.

\section{Material and Methods}

The experiment was carried out at the Experimental Station facilities of the Pendencia Experimental Station belonging to the Paraiba State Agriculture and Livestock Research Agency S.A (EMEPA) located in the town of Soledade in the state of Paraíba.

Fifty-four non-castrated lambs (18 Santa Inês lambs, 18 F1 Dorper $\times$ Santa Inês lambs and 18 F1 Santa Inês $\times$ undefined breed lambs) with an average age of $150 \mathrm{~d}$ and live weight of $22.6 \mathrm{~kg}$ at the onset of the experiment were used. Animals were distributed in a completely randomized design in individual stalls measuring $0.80 \mathrm{~m} \times 1.20 \mathrm{~m}$ with free access to feed and water troughs, and they stayed in feedlot until reaching an average live weight for slaughter of $36.0 \mathrm{~kg}$. A maximal feedlot period of $63 \mathrm{~d}$ was established. Thus, at the end of this period, the lambs that had not reached the pre-established live weight were also slaughtered. The period of adaptation to the diets was $14 \mathrm{~d}$, and weightings were performed every $14 \mathrm{~d}$.
Two complete isoprotein diets containing $170 \mathrm{~g} / \mathrm{kg}$ crude protein were used (Table 1). The diet with the highest energy concentration had $2.90 \mathrm{Mcal} \mathrm{ME} / \mathrm{kg} \mathrm{DM}$ for a weight gain of $250 \mathrm{~g} / \mathrm{d}$, which was based on the NRC (1985) for lambs with $20.0 \mathrm{~kg}$ of live weight and moderate growth; the diet with the lowest concentration of energy had 2.40 Mcal metabolizable energy - ME/kg DM for a weight gain of $200 \mathrm{~g} / \mathrm{d}$.

An average dry matter intake (DMI) was established at $5 \%$ of the live weight, and it was readjusted and weighed daily so that there were $10 \%$ of leftovers. The calculation of DMI was subsequently determined. When the animals reached the pre-established weight or maximal feedlot time period, they were subjected to an 18-h fast of solids and 12-h fast of liquids. After the fast, the animals were weighed to calculate their average daily gain (ADG) and feed conversion (DMI/ADG) and then slaughtered.

Corporal score evaluation was carried out by two examiners according to the methodology described by Cezar \& Sousa (2006). For the attribution of scores, evaluations were made before slaughter by visual examination and manual palpation of the lumbar and tail insertion areas of the lambs using a scale of 1 to 5 with intervals of 0.5.

Water intake was evaluated weekly during the entire experimental period by quantifying the offer and leftovers for $48 \mathrm{~h}$. Determination of the water intake began at 7:00 AM when 7.5 L of water were offered in 10-L plastic containers. After $24 \mathrm{~h}$, the remanining water was weighed to estimate daily intake, and this process was repeated for an additional $24 \mathrm{~h}$.

Table 1 - Nutritional and chemical composition of the experimental diets with two levels of energy

\begin{tabular}{|c|c|c|}
\hline \multirow[t]{2}{*}{ Nutritional composition } & \multicolumn{2}{|c|}{ Levels of energy of diet (Mcal ME/kg DM) } \\
\hline & 2.40 & 2.90 \\
\hline Tifton hay (g/kg) & 500 & 212 \\
\hline Soybean meal (g/kg) & 168 & 208 \\
\hline Wheat bran $(\mathrm{g} / \mathrm{kg})$ & 190 & - \\
\hline Soybean oil (g/kg) & - & 20 \\
\hline \multicolumn{3}{|l|}{ Chemical composition } \\
\hline Crude protein (g/kg) & 170,00 & 170.00 \\
\hline Metabolizable energy (Mcal/kg DM) & 2.40 & 2.90 \\
\hline Neutral detergent fiber $(\mathrm{g} / \mathrm{kg})$ & 520.50 & 270.32 \\
\hline Total digestible nutrients $(\mathrm{g} / \mathrm{kg})$ & 660.22 & 800.06 \\
\hline Ether extract $(\mathrm{g} / \mathrm{kg})$ & 20.29 & 40.89 \\
\hline
\end{tabular}

* Represents the mineral composition per kilogram as follows: $147 \mathrm{~g}$ of Na; $120 \mathrm{~g}$ of Ca; $87 \mathrm{~g}$ of P; $18 \mathrm{~g}$ of S; $3.8 \mathrm{mg}$ of Zn; $3500 \mathrm{mg}$ of Fe; $1.3 \mathrm{mg}$ of Mn; $870 \mathrm{mg}$ of Fl; $590 \mathrm{mg}$ of $\mathrm{Cu} ; 300 \mathrm{mg}$ of Mo; $80 \mathrm{mg}$ of I; $40 \mathrm{mg}$ of Co; $20 \mathrm{mg}$ of Cr; $15 \mathrm{mg}$ of Se; $250 \mathrm{mg}$ of vitamin A (UI); $100 \mathrm{mg}$ of vitamin D (UI); and $500 \mathrm{mg}$ of vitamin E (UI). $\mathrm{ME}$ - metabolizable energy; DM - dry matter. 
After bleeding and skinning, the gastrointestinal content, skin, viscera, head, hoofs, and genital organs were removed. The obtained carcass was then washed and weighed to determine the hot carcass weight (HCW). The empty corporal weight (ECW) was obtained by the difference between the final live weight (FLW) and the gastrointestinal content weight.

After cold storage at $4{ }^{\circ} \mathrm{C}$ for $24 \mathrm{~h}$, the cold carcasses were weighed to determine the cold carcass weight (CCW).

Measurements of weight gain during time spent in feedlot, average dry matter consumption, time spent in feedlot, cost of each diet, cost of vaccines and cost of medications were used to calculate the gross profit margin (GPM). The methodology applied to determine the GPM had been previously described by Cartaxo et al. (2008).

The following formula was used to determine the GPM:

$$
\text { GPM }=(\text { WGC } \times 3.95)-\text { ADI }- \text { EVM }
$$

where GPM is the gross profit margin (US\$/animal); WGC is the weight gain in feedlot; 3.95 is the price per live kilogram of lamb in the region (US\$); ADI is the average dry matter intake $(\mathrm{kg} \mathrm{DM}) \times$ period of feedlot (days) $\times$ cost of diet(US\$); and EVM is the expenses associated with vaccines and medications (US\$).

Data were submitted to variance analysis with a $3 \times 2$ factorial arrangement (three genotypes and two energy levels in the diet). The averages were compared by the Tukey test $(\alpha=0.05)$.

\section{Results and Discussion}

There was no interaction of genotype and diet for dry matter intake and water intake (Table 2). There was an effect of the diet on the DMI in a unit of metabolic body weight because metabolic weight homogenizes animals by superficial area, eliminating the effect of live weight. The same effect occurred with the intake expressed as a percentage of live weight, in which the diet with the higher level of energy and lower fiber content had an inferior intake when compared with the diet containing $2.40 \mathrm{Mcal} / \mathrm{kg} \mathrm{DM}$. These results may be attributed to the greater energy density and lower percentage of NDF present in the diet containing $2.90 \mathrm{Mcal} / \mathrm{kg}$ DM because the lambs fed this diet needed smaller quantities of dry matter to meet their nutritional requirements. Alves et al. (2003) evaluated three levels of metabolizable energy in the diet $(2.42 \mathrm{Mcal} / \mathrm{kg} \mathrm{DM}$, $2.66 \mathrm{Mcal} / \mathrm{kg} \mathrm{DM}$ and $2.83 \mathrm{Mcal} / \mathrm{kg} \mathrm{DM}$ ) in Santa Inês lambs slaughtered at approximately $31.0 \mathrm{~kg}$, and they observed intake values similar to those found in this study.

The diet with the lower energy density resulted in a greater amount of water intake when expressed in units of metabolic body weight and percentage of body weight. This result can be explained by the greater amount of DMI in units of metabolic body weight and percentage of body weight obtained by the lambs fed the diet containing 2.40 $\mathrm{Mcal} / \mathrm{kg}$ DM. It is well known that there is a high and significant correlation between DMI and water intake. According to the NRC (1985), the voluntary intake of water in sheep is two to three times the intake of dry matter. The results obtained in this research agree with the NRC report.

No effect was observed for the interaction between genotype and diet (Table 3) for final body weight, average daily gain, corporal score and period of time spent in feedlot. The final body weight of the lambs subjected to the diet containing $2.90 \mathrm{Mcal} / \mathrm{kg}$ DM was higher than lambs in the diet with a $2.40 \mathrm{Mcal} / \mathrm{kg}$ DM. However, there was no effect for genotype with regard to the final body weight of the lambs.

Lambs fed $2.90 \mathrm{Mcal} / \mathrm{kg}$ DM-diet had a higher average daily gain when compared with the lambs subjected to the diet containing 2.40 Mcal/kg DM. The diet with the highest concentration of energy has a greater proportion of volatile fatty acids, mainly ruminal propionate (Priolo et al., 2002; Clementino et al., 2007). After being absorbed by the rumen wall, these fatty acids become the main substrate of hepatic gluconeogenesis, resulting in a greater availability of energy in the form of glucose and, consequently, a greater daily average weight gain.

Table 2 - Dry matter intake (DMI) and water intake (WI) according to diet (D) and genotype (G)

\begin{tabular}{|c|c|c|c|c|c|c|c|c|c|}
\hline Variable & \multicolumn{2}{|c|}{ Diet (Mcal ME/kg DM) } & \multicolumn{3}{|c|}{ Genotype } & \multicolumn{3}{|c|}{ Effect } & CV (\%) \\
\hline DMI (kg/day) & 1.15 & 1.11 & 1.14 & 1.09 & 1.16 & 0.267 & 0.320 & 0.916 & 12.66 \\
\hline DMI (g/kg BW) & $30.27 a$ & $30.03 b$ & 30.12 & 30.07 & 30.26 & 0.002 & 0.136 & 0.700 & 8.91 \\
\hline WI (kg/day) & 3.71 & 3.57 & 3.69 & 3.69 & 3.54 & 0.228 & 0.467 & 0.838 & 11.11 \\
\hline WI $\left(g / k^{0.75}\right)$ & $256.46 \mathrm{a}$ & $241.24 b$ & 254.69 & 248.23 & 243.62 & 0.049 & 0.491 & 0.938 & 11.16 \\
\hline
\end{tabular}

DP - Dorper; SI - Santa Inês; UB - undefined breed; ME - metabolizable energy; BW - body weight; DM - dry matter. 
Borton et al. (2005) evaluated the performance of Targhee $\times$ Hampshire lambs subjected to two feeding systems as follows: diet with concentrate $(2.78 \mathrm{Mcal} / \mathrm{kg}$ $\mathrm{DM}$ ) and diet with forage. They verified that the lambs fed concentrate diet have a greater average daily gain $(330 \mathrm{~g} / \mathrm{d})$ when compared with lambs that received forage $(120 \mathrm{~g} / \mathrm{d})$. In addition, Sheridan et al. (2003) evaluated Mutton Merino lambs fed a diet containing $2.90 \mathrm{Mcal} / \mathrm{kg} \mathrm{DM}$ or $2.37 \mathrm{Mcal} / \mathrm{kg}$ DM and slaughtered at $28 \mathrm{~d}$ or 56 of feedlot reported a higher average daily gain for the animals subjected to the diet containing $2.90 \mathrm{Mcal} / \mathrm{kg} \mathrm{DM}$ in both periods of finishing. These authors reported a higher average daily gain for the animals subjected to the diet containing $2.90 \mathrm{Mcal} / \mathrm{kg}$ DM in both periods of finishing.

The results of average daily gain reached with the Santa Inês animals and their crossbreds were similar, which corroborates several previous results obtained in Brazil (Furusho-Garcia et al., 2000; Yamamoto et al., 2005; Sá et al., 2005; Cartaxo et al., 2008; Furusho-Garcia et al., 2010).

Lambs fed diet containing $2.90 \mathrm{Mcal} / \mathrm{kg} \mathrm{DM}$ had a higher corporal score. Corporal score is an individual measurement that indicates the quantity of muscle and adipose tissue present in the body of an animal (Cezar \& Sousa, 2006). Animals fed a diet containing a greater concentration of lipids may deposit more fat in the body (Berchielli et al., 2006), leading to a higher corporal score.

Dorper $\times$ Santa Inês lambs showed higher corporal score than Santa Inês lambs. However, the corporal score of Santa Inês $\times$ undefined breed lambs was similar to the Dorper $\times$ Santa Inês. The Dorper $\times$ Santa Inês lambs were superior to the Santa Inês lambs because the crossbred animals had $50 \%$ of a breed specialized for meat (slaughter) in their genotype composition. Therefore, the Dorper $x$ Santa Inês crossbred lambs characteristically had a higher covering of fat and, consequently, higher corporal condition scores.

The period of time spent in the feedlot was influenced by the diet (Table 3). Lambs fed a greater energy density diet required less time in the feedlot (56 d) to reach the slaughtering live weight when compared with the lambs that received the lower density energy diet (61 d). Similarly, Alves et al. (2003) observed that lambs fed a diet containing a higher level of energy (2,83 Mcal/kg DM) remain in the feedlot for $76 \mathrm{~d}$ and that lambs fed a diet containing a lower level of energy (2,42 Mcal/kg DM) require $98 \mathrm{~d}$ to reach a live weight of $33.0 \mathrm{~kg}$.

There was interaction of diet and genotype for the feed conversion and carcass yield parameters (Table 4). The Dorper $\times$ Santa Inês lambs had a similar feed conversion with both diets, demonstrating that the distinct levels of energy did not affect the usage of diet for these lambs. However, Santa Inês and Santa Inês $\times$ undefined breed lambs presented better feed conversion in the diet with $2.90 \mathrm{Mcal} / \mathrm{kg} \mathrm{DM}$ when compared with the diet with $2.40 \mathrm{Mcal} / \mathrm{kg} \mathrm{DM}$, indicating that a diet with a greater concentration of energy is necessary to obtain a better utilization of diet with these genotypes. Similarly, Mahgoub et al. (2000) evaluated the effect of three different levels of energy (2.08 Mcal/kg DM, 2,38 Mcal/kg DM and $2.68 \mathrm{Mcal} / \mathrm{kg} \mathrm{DM}$ ) in Omani lambs, and observed that feed conversion improves as the dietary energy level increases.

In this study, it was also verified that the feed conversion of Santa Inês $\times$ undefined breed lambs fed the diet containing $2.40 \mathrm{Mcal} / \mathrm{kg} \mathrm{DM}$ was inferior to the feed conversion of Dorper $\times$ Santa Inês lambs fed the same diet, and the feed conversion of the Santa Inês lambs was similar to the Dorper $\times$ Santa Inês and Santa Inês $\times$ undefined breed lambs. This result demonstrates that the lambs crossbred with breeds specialized for slaughtering and subjected to the diet with $2.40 \mathrm{Mcal} / \mathrm{kg} \mathrm{DM}$ were more efficient in converting dry matter into body weight when compared with Santa Inês $\times$ undefined breed crossbred lambs.

There was no effect of genotype on feed conversion of lambs fed a diet containing a higher level of energy. This result indicates that the Santa Inês lambs and their crossbreds, when finished in feedlot and subjected to the diets containing high concentration of energy in a similar way convert the diet body weight.

Table 3 - Initial body weight (IW), final body weight (FW), average daily gain (ADG), corporal score (CS) and period of time spent in the feedlot (FT) according to the diet (D) and genotype (G)

\begin{tabular}{|c|c|c|c|c|c|c|c|c|c|}
\hline \multirow[t]{2}{*}{ Variable } & \multicolumn{2}{|c|}{ Diet (Mcal ME/kg DM) } & \multicolumn{3}{|c|}{ Genotype } & \multicolumn{3}{|c|}{ Effect } & \multirow[b]{2}{*}{$\mathrm{CV}(\%)$} \\
\hline & 2.40 & 2.90 & SI & $\mathrm{DP} \times \mathrm{SI}$ & $\mathrm{SI} \times \mathrm{UB}$ & $\mathrm{D}$ & G & $\mathrm{D} \times \mathrm{G}$ & \\
\hline IW (kg) & 22.88 & 22.40 & 23.28 & 22.72 & 22.48 & 0.266 & 0.106 & 0.412 & 7.00 \\
\hline FW (kg) & $35.28 b$ & $36.61 \mathrm{a}$ & 36.61 & 35.50 & 35.72 & 0.049 & 0.355 & 0.240 & 6.73 \\
\hline ADG (g/day) & $204.15 b$ & $258.15 a$ & 240.55 & 223.02 & 229.88 & 0.0003 & 0.582 & 0.053 & 21.93 \\
\hline CS (1-5) & $3.40 \mathrm{~b}$ & $3.63 a$ & $3.30 \mathrm{~B}$ & $3.75 \mathrm{~A}$ & $3.50 \mathrm{AB}$ & 0.019 & 0.002 & 0.886 & 9.62 \\
\hline FT (days) & $61.44 \mathrm{a}$ & $56.26 b$ & 56.77 & 60.66 & 59.11 & 0.002 & 0.139 & 0.255 & 9.84 \\
\hline
\end{tabular}

DP - Dorper; SI - Santa Inês; UB - undefined breed. 
Other authors have studied the same genotypes evaluated in this study subjected to high energy diets, and did not find any difference between genotypes for feed conversion (Oliveira et al., 2003; Haddad \& Husein, 2004; Carvalho et al., 2005; Moharrery, 2007; Cartaxo et al., 2008; Araújo Filho et al., 2010).

Dorper $\times$ Santa Inês lambs and Santa Inês lambs had higher carcass yields when fed the diet containing $2.90 \mathrm{Mcal} / \mathrm{kg}$ DM. However, no difference in carcass yield was observed between the two diets for the Santa Inês $x$ undefined breed lambs, demonstrating that the increase in the level of energy did not produce superior carcass yields for these animals, which may be due to the genetic composition. The Santa Inês $\times$ undefined breed genotype was formed by $50 \%$ undefined breed; this genotype is characterized by a greater rusticity and adaptability to adverse environments, but to the detriment of meat production. The opposite situation occurs with crossbred animals that have a genetic composition of typically meatproducing breeds, such as Santa Inês and Dorper.

When the analysis considered the effect of diet on the genotype, a difference was observed only with the diet containing 2.90 Mcal/kg DM, where Dorper $\times$ Santa Inês lambs had higher carcass yields when compared with Santa Inês $\times$ undefined breed lambs, and Santa Inês lambs carcass yields were similar to the Santa Inês $\times$ undefined breed lambs and Dorper $\times$ Santa Inês lambs. These results show that the commercialization of Dorper $\times$ Santa Inês lambs carcasses can be a more economically profitable option when compared with Santa Inês $\times$ undefined breed lambs. On the other hand, when the Santa Inês and their crossbreds are finished in feedlot and fed a diet containing a lower level of energy, marketing can be with alive animals.

An interaction of the diet and genotype was verified for gross profit margin (Table 5). The Santa Inês $\times$ undefined breed lambs and Santa Inês lambs had a difference in gross profit margin between the diets, showing that the concentration of energy influenced the economical results for these lambs, and a larger profit margin was observed with the higher energy diet.

For the effect of the diet on the genotype, the Dorper $\times$ Santa Inês lambs had a similar economic result when fed $2.40 \mathrm{Mcal} / \mathrm{kg}$ DM, which was better compared with Santa Inês $\times$ undefined breed lambs. In this diet the Santa Inês lambs showed gross profit margin similar to the two genotypes, demonstrating to be an option for meat production.

Based on a better feed conversion and larger gross profit margin reached by the Dorper $\times$ Santa Inês genotype with the lower energy diet when compared with the Santa Inês $\times$ undefined breed lambs, one can affirm that Dorper $\times$ Santa Inês lambs subjected to the diet with less energy had an economic performance superior to the Santa Inês $x$ undefined breed lambs. With regard to the diet containing higher energy concentration Santa Inês lambs and their crossbreds had similar economical results, and can be successfully used in feedlot finishing.

Table 4 - Feed conversion, biological yield, hot carcass yield and cold carcass yield

\begin{tabular}{|c|c|c|c|c|c|}
\hline \multirow[t]{2}{*}{ Variable } & \multirow[t]{2}{*}{ Diet (Mcal ME/kg DM) } & \multicolumn{3}{|c|}{ Genotype } & \multirow[b]{2}{*}{ CV (\%) } \\
\hline & & SI & $\mathrm{DP} \times \mathrm{SI}$ & $\mathrm{SI} \times \mathrm{UB}$ & \\
\hline \multicolumn{6}{|c|}{ Feed conversion } \\
\hline & $\begin{array}{l}2.40 \\
2.90\end{array}$ & $\begin{array}{c}5.82 \mathrm{aAB} \\
4.16 \mathrm{~b}\end{array}$ & $\begin{array}{c}5.28 \mathrm{~B} \\
4.86\end{array}$ & $\begin{array}{c}6.39 \mathrm{aA} \\
4.30 \mathrm{~b}\end{array}$ & $\begin{array}{l}15.84 \\
16.54\end{array}$ \\
\hline \multicolumn{6}{|c|}{ Biological yield (\%) } \\
\hline & $\begin{array}{l}2.40 \\
2.90\end{array}$ & $\begin{array}{c}45.85 \mathrm{a} \\
50.43 \mathrm{bAB}\end{array}$ & $\begin{array}{c}\text { 47.53a } \\
51.01 \mathrm{bA}\end{array}$ & $\begin{array}{c}47.73 \\
48.57 \mathrm{~B}\end{array}$ & $\begin{array}{l}4.00 \\
3.89\end{array}$ \\
\hline \multicolumn{6}{|c|}{ Hot carcass yield (\%) } \\
\hline & $\begin{array}{l}2.40 \\
2.90\end{array}$ & $\begin{array}{c}45.46 a \\
49.99 b A B\end{array}$ & $\begin{array}{c}47.12 \mathrm{a} \\
50.57 \mathrm{bA}\end{array}$ & $\begin{array}{c}47.33 \\
48.13 \mathrm{~B}\end{array}$ & $\begin{array}{l}3.99 \\
3.87\end{array}$ \\
\hline \multicolumn{6}{|c|}{ Cold carcass yield (\%) } \\
\hline & $\begin{array}{l}2.40 \\
2.90\end{array}$ & $\begin{array}{c}44.02 \mathrm{a} \\
48.58 \mathrm{bAB}\end{array}$ & $\begin{array}{c}45.56 \mathrm{a} \\
49.49 \mathrm{bA}\end{array}$ & $\begin{array}{c}46.03 \\
47.38 \mathrm{~B}\end{array}$ & $\begin{array}{l}4.07 \\
4.06 \\
\end{array}$ \\
\hline
\end{tabular}

Distinct letters (lower case in the columns and uppercase on the rows) indicate significant differences according to the Tukey test at $5 \%$ probability.

ME - metabolizable energy; DM - dry matter; SI - Santa Inês; DP - Dorper; UB - undefined breed; CV - coefficient of variation. 
Table 5 - Gross profit margin (GPM) according to the diet and genotype of the lambs

\begin{tabular}{|c|c|c|c|c|c|}
\hline \multirow[t]{2}{*}{ Variable } & \multirow[t]{2}{*}{ Diet (Mcal ME/kg DM) } & \multicolumn{3}{|c|}{ Genotype } & \multirow[b]{2}{*}{$\mathrm{CV}(\%)$} \\
\hline & & SI & $\mathrm{DP} \times \mathrm{SI}$ & $\mathrm{SI} \times \mathrm{UB}$ & \\
\hline \multirow[t]{2}{*}{ Observations } & 2.40 & 9 & 9 & 9 & \\
\hline & 2.90 & 9 & 9 & 9 & \\
\hline \multirow[t]{2}{*}{ Cost of diet/kg DM (U\$) } & 2.40 & 0.35 & 0.35 & 0.35 & \\
\hline & 2.90 & 0.42 & 0.42 & 0.42 & \\
\hline \multirow[t]{2}{*}{ Dry matter intake (kg) } & 2.40 & 1.17 & 1.13 & 1.18 & \\
\hline & 2.90 & 1.13 & 1.06 & 1.15 & \\
\hline \multirow[t]{2}{*}{ Average gain (kg) } & 2.40 & 12.17 & 13.34 & 11.65 & \\
\hline & 2.90 & 14.47 & 13.31 & 14.83 & \\
\hline \multirow[t]{2}{*}{ Period of feedlot } & 2.40 & 59.88 & 61.44 & 63.00 & \\
\hline & 2.90 & 53.66 & 59.88 & 55.22 & \\
\hline Expenses with vaccines and medicine (U\$) & & 0.50 & 0.50 & 0.50 & \\
\hline \multirow[t]{2}{*}{ Gross profit margin (U\$/animal) } & 2.40 & $23.28 \mathrm{bAB}$ & $28.02 \mathrm{~A}$ & $19.56 \mathrm{aB}$ & \\
\hline & 2.90 & $31.39 a$ & 25.54 & $31.62 b$ & \\
\hline
\end{tabular}

Distinct letters (lower case in the columns and uppercase on the rows) indicate significant differences according to the Tukey test at $5 \%$ probability ME - metabolizable energy; DM - dry matter; SI - Santa Inês; DP - Dorper; UB - undefined breed; CV - coefficient of variation.

\section{Conclusions}

A diet with higher concentration of energy (2.90 Mcal) is recommended for finishing lambs in feedlot regardless of the genotype, for producing greater body weight gain, better corporal condition and a shorter time spent in feedlot. The Santa Inês breed and their crossbreds with the Dorper or undefined breed, when submjected to a diet with a higher concentration of energy (2.90 Mcal), have similar performance and economical results. The crossbreeding of Dorper with Santa Inês improves feed conversion and increases gross profit margin compared with the crossbreeding of Santa Inês with undefined breed, when subjected to a diet with lower energy concentration (2.40 Mcal). The Dorper $\times$ Santa Inês lambs show greater carcass yields than the Santa Inês $\times$ undefined breed lambs when fed a diet containing a lower concentration of energy.

\section{References}

ALFONSO, M.; SAÑUDO, C.; BERGE, P. et al. Influential factors in lamb meat quality, acceptability of specific designations, production system and product quality in sheep and goats. Options Mediterraneennes, v.46, p.19-28, 2001.

ALVES, K.S.; CARVALHO, F.F.R.; VÉRAS, A.S.C. et al. Níveis de energia em dietas para ovinos Santa Inês: Desempenho. Revista Brasileira de Zootecnia, v.32, p.1937-1944, 2003.

ARAÚJO FILHO, J.T.; COSTA, R.G.; FRAGA, A.B. et al. Desempenho e composição da carcaça de cordeiros deslanados terminados em confinamento com diferentes dietas. Revista Brasileira de Zootecnia, v.39, p.363-371, 2010.

BERCHIELLI, T.T.; PIRES, A.V.; OLIVEIRA, S.G. Nutrição de ruminantes. Jabotical: Funep, 2006. p.287-309.

BORTON, R.L,; LOERCH, S.C.; MCCLURE, K.E. et al. Comparison of characteristics of lambs fed concentrate or grazed on ryegrass to traditional or heavy slaughter weights, I, Production, carcass, and organoleptic characteristics. Journal of Animal Science, v.83, p.679-685, 2005.
CAMURÇA, D.A.; NEIVA, J.N.M.; PIMENTEL, J.C.M. et al. Desempenho produtivo de ovinos alimentados com dietas à base de feno de gramíneas tropicais. Revista Brasileira de Zootecnia, v.31, p.2113-2122, 2002.

CARTAXO, F.Q.; SOUSA, W.H.; CEZAR, M.F. et al. Efeitos do genótipo e da condição corporal sobre o desempenho de cordeiros terminados em confinamento. Revista Brasileira de Zootecnia, v.37, p.1483-1489, 2008.

CARVALHO, S.; VERGUEIRO, A.; KIELING, R. et al. Desempenho e características de carcaça de cordeiros das raças Texel, Suffolk e cruza Texel x Suffolk. Ciência Rural, v.35, p.1155-1160, 2005.

CEZAR, M.F.; SOUSA, W.H. Avaliação e utilização da condição corporal como ferramenta de melhoria da reprodução e produção de ovinos e caprinos de corte. Revista Brasileira de Zootecnia, v.35, p.541-565, 2006.

CLEMENTINO, R.H.; SOUSA, W.H.; MEDEIROS, A.N. et al. Influência dos níveis de concentrado sobre os cortes comerciais, os constituintes não-carcaça e os componentes da perna de cordeiros confinados. Revista Brasileira de Zootecnia, v.36, p.681-688, 2007.

FURUSHO-GARCIA, I.F.; PEREZ, J.R.O.; TEIXEIRA, J.C. et al. Desempenho de cordeiros Texel x Bergamácia, Texel x Santa Inês e Santa Inês puros, terminados em confinamento, alimentados com casca de café como parte da dieta. Revista Brasileira de Zootecnia, v.29, p.564-572, 2000.

FURUSHO-GARCIA, I.F.; PEREZ, J.R.O.; BONAGURIO, S. et al. Estudo alométrico dos cortes de cordeiros Santa Inês puros e cruzas. Revista Brasileira de Zootecnia, v.35, n.4, p.1416-1422, 2006.

FURUSHO-GARCIA, I.F.; COSTA, T.I.R.; ALMEIDA, A.K. et al. Performance and carcass characteristics of Santa Inês pure lambs and crosses with Dorper e Texel at different management systems. Revista Brasileira de Zootecnia, v.39, p.1313-1321, 2010.

HADDAD, S.G.; HUSEIN, M,Q. Effect of dietary energy density on growth performance and slaughtering characteristics of fattening Awassi lambs. Livestock Production Science, v.87, p.171-177, 2004.

MAHGOUB, O.; LU, C.D.; EARLY, R.J. Effects of dietary energy density on feed intake, body weight gain and carcass chemical composition of Omani growing lambs. Small Ruminant Research, v.37, p.35-42, 2000.

MINISTÉRIO DA AGRICULTURA, PECUÁRIA E ABASTECIMENTO - MAPA. Comércio exterior brasileiro. 
[2009]. Available at: <www.agricultura.gov.br/portal/page?_ pageid= 33,969929\&_dad=portal\&_schema=PORTAL $>$ Accessed on: Jan. 20, 2009.

MOHARRERY, A. Effect of docking and energy of diet on carcass fat characteristics in fat-tailed Badghisian sheep. Small Ruminant Research, v.69, p.208-216, 2007.

NATIONAL RESEARCH COUNCIL - NRC. Nutrient requirements of sheep. 6.ed. Washington, D.C.: National Academy Press, 1985. 99p.

OLIVEIRA, M.V.M.; PEREZ, J.R.O.; GARCIA, I.F.F. et al. Desempenho de cordeiros das raças Bergamácia e Santa Inês, terminados em confinamento recebendo dejetos de suínos como parte da dieta. Revista Brasileira de Zootecnia, v.32, p.1391-1396, 2003.

PRIOLO, A.; MICOLA, D.; AGABRIELA, J. et al. Effect of grass or concentrate feeding systems on lamb carcass and meat quality. Meat Science, v.62, p.179-185, 2002.
SÁ, J.L.; SIQUEIRA, E.R.; SÁ, C.O. et al. Características de carcaça de cordeiros Hampshire Down e Santa Inês sob diferentes fotoperíodos. Pesquisa Agropecuária Brasileira, v.40, p.289-297, 2005.

SAÑUDO C.; SANCHEZ, A.; ALFONSO M. Small ruminant production systems and factors affecting lamb meat quality. Meat Science, v.49, S29-S64, 1998.

SHERIDAN, R.; FERREIRA, A.V.; HOFFMAN, L.C. Production efficiency of South African Mutton Merino lambs and Boer goat kids receiving either a low or a high energy feedlot diet. Small Ruminant Research, v.50, p.75-82, 2003.

SIQUEIRA, E.R.; SIMÕES, C.D.; FERNANDES, S. Efeito do sexo e do peso ao abate sobre a produção de carne de cordeiro. I. Velocidade de crescimento, caracteres quantitativos da carcaça, $\mathrm{pH}$ da carne e resultado econômico. Revista Brasileira de Zootecnia, v.30, p.844-848, 2001.

YAMAMOTO, S.M.; MACEDO, F.A.F.; ZUNDT, M. et al. Fontes de óleo vegetal na dieta de cordeiras em confinamento. Revista Brasileira de Zootecnia, v.34, p.703-710, 2005. 